\title{
Language attitudes, practices and identity in the new Lithuanian diaspora
} Meilutė RAMONIENE் $\dot{1}^{1}$ and Jogilè Teresa RAMONAITE் $\dot{E}^{2}$

\author{
${ }^{1}$ Vilnius University \\ Vilnius, Lithuania \\ ${ }^{2}$ Institute of the Lithuanian language \\ Vilnius, Lithuania
}

\begin{abstract}
After the changes in the socio-political situation in many countries of Eastern and Central Europe in the last decade of the $20^{\text {th }}$ century, these countries experienced a major growth of emigration. In the context of the European Union, Lithuania is one of the countries that has faced the highest rates of emigration. The quick and somewhat sporadic emigration mainly for economic reasons is of interest both to linguists and language policy makers in order to support and give guidelines for the maintenance of the heritage language and identity. This paper deals with the data of the new postSoviet wave of Lithuanian emigrants analysing the language behaviour and language attitudes. The aim is to look into the issues of language attitudes, practices and identity through the tripartite theoretical model - beliefs, emotions and declared language practices - of this wave and to compare it to the overall context of Lithuanian diaspora. The data analysed in this paper has been collected using quantitative (online surveys) and qualitative methods (in-depth interviews) in two research projects in the Lithuanian diaspora in 2011-2017. The main focus is on the use of the heritage Lithuanian language in various domains (home, community, friendship, church), comparing the use of Lithuanian by the post-Soviet emigrants with the language behaviour of the emigrants of earlier emigration waves. The results show equally positive beliefs and affective attitudes of the post-Soviet emigrants compared to previous waves, but a different language behaviour especially when comparing to the emigrants of the end of World War II.
\end{abstract}

Keywords: Lithuanian diaspora, language maintenance, language attitudes

\section{For citation:}

Ramonienè, Meilutè \& Jogilè Teresa Ramonaitè. 2021. Language attitudes, practices and identity in the new Lithuanian diaspora. Russian Journal of Linguistics 25 (4). 1024-1046. https://doi.org/10.22363/2687-0088-2021-25-4-1024-1046 
Научная статья

\title{
Языковые установки, практики и идентичность в новой литовской диаспоре Мейлуте РАМОНИЕНЕ ${ }^{1}$,̆огиле Тереса РАМОНАЙТЕ ${ }^{2}$
}

\author{
${ }^{1}$ Вильнюсский университет \\ Вильнюс, Литва \\ ${ }^{2}$ Институт литовского языка \\ Вильнюс, Литва
}

\begin{abstract}
Аннотация
Перемены в социополитической ситуации, произошедшие в последнее десятилетие XX в. во многих странах Восточной и Центральной Европы, привели к росту эмиграции из этих стран. Литва входит в число стран Евросоюза с наиболее значительными эмиграционными потоками. Быстрая и в некоторой степени спорадическая эмиграция, главным образом по экономическим причинам, представляет интерес как для лингвистов, так и для лиц, определяющих языковую политику, поскольку она поддерживает и дает рекомендации по сохранению унаследованного литовского языка и этнической идентичности. В статье рассматриваются данные новой постсоветской волны литовских эмигрантов, анализируется их языковое поведение и языковые установки. Цель данного исследования состоит в том, чтобы изучить проблемы языковых установок, практик и идентичности через трехстороннюю теоретическую модель - убеждений, эмоций и декларируемых языковых практик - этой волны и сравнить это с общим контекстом литовской диаспоры. Данные, проанализированные в этой статье, были собраны с использованием количественных (онлайн-опросы) и качественных (глубинные интервью) методов в рамках двух исследовательских проектов в литовской диаспоре в 2011-2017 гг. Авторы уделяют основное внимание использованию литовского языка в различных сферах (дома, общины, дружеские отношения, церкви), сравнивая его применение постсоветскими эмигрантами с языковым поведением эмигрантов из более ранних волн эмиграции. Результаты показывают одинаково позитивные убеждения и эмоциональное отношение постсоветских эмигрантов по сравнению с предыдущими волнами, но иное языковое поведение, особенно по сравнению с эмигрантами конца Второй мировой войны.

Ключевые слова: литовская диаспора, сохранение языка, языковые установки
\end{abstract}

\section{Для цитирования:}

Ramonienè M., Ramonaitė J.T. Language attitudes, practices and identity in the new Lithuanian diaspora. Russian Journal of Linguistics. 2021. Vol. 25. № 4. P. 1024-1046. https://doi.org/10.22363/2687-0088-2021-25-4-1024-1046

\section{Introduction}

After the changes in the socio-political situation in many countries of Eastern and Central Europe in the last decade of the $20^{\text {th }}$ century, these countries experienced a major growth of emigration. In the context of the European Union, Lithuania is one of the countries that have experienced the highest rates of emigration. This immense emigration causes various problems and challenges for the demographic development, economic growth and maintenance of cultural identity of Lithuania (Martinaitis \& Žvalionyte 2007), it causes concern to the society and the state institutions and also evokes the attention of various scholars (Kuzmickaitė 2003, Čiubrinskas 2004, 2005, 2011, Kuznecovienè 2008, Liubinienè 
2009, Barcevičius 2012, Aleksandravičius 2013). Researchers study Lithuanian communities in various countries of the world, some of them founded at the end of the $19^{\text {th }}$ century, and analyse different aspects of emigration. However, according to the historian Egidijus Aleksandravičius (2013) who studies the Lithuanian diaspora, research on the current emigration wave and the changes in the Lithuanian diaspora is only beginning and there are still many unknown aspects about it.

The new post-Soviet emigration wave differs from others waves in various aspects. The reasons for emigration are different and the destinations of emigration have greatly changed. Countries like Ireland, Norway, Spain have never been the destination of Lithuanian emigration before and the most recent wave of emigration to these countries is quite numerous. The emigration towards the United Kingdom has become a lot more intense. The numbers of those leaving to Germany and the USA have increased and also, many Lithuanians are going to Sweden, Denmark, the Netherlands, Iceland and other countries where previously there was no Lithuanian diaspora. As Aleksandravičius indicates (2013: 567), the settling of post-Soviet emigrants in these new places was rather different not only in comparison to the earlier waves but also among different countries. Inevitably, also the structure and the problems of the renewed diaspora were different. Some of the communities of new emigrants have already been studied to a certain extent by sociologists and anthropologists, however the linguistic behaviour of these new emigrants has not been extensively studied.

The conceptual framework of this paper is based on the tripartite model of language attitudes, the components of which are cognitive, affective and behavioural (Edwards 1982, Breckler 1984, Garret et al. 2003, Garret 2010 among others). The cognitive component contains beliefs about the attitude object, about the relationship between what is considered as socially significant. Even though theoretically presented as the second component - affective, it is "usually argued that, even if beliefs do not have any affective content, they may trigger and indeed be triggered by strong affective reactions" (Garret 2003: 10). "This affective aspect of attitudes is a barometer of favourability and unfavourability, or the extent to which we approve or disapprove of the attitude object" (Garret 2010: 23). Also, the cognitive and the affective components are often considered in combination.

The third component of the tripartite model is behaviour. This means there is a link between attitudes and behaviour as attitudes can predispose certain behaviour. Even though most theorists agree that behaviour is a constitutive part of attitudes, the manner and the extent is debated. Some studies show that attitudes do not necessarily determine the behaviour (Hanson 1980), that the correlation between cognition, affect and behaviour can be only a moderate one (Breckler 1984). Therefore, in research on attitudes the relation between attitudes and behaviour is a highly important issue (Garret 2010).

The complex structure of the Lithuanian diaspora permits the comparison of language attitudes of different emigration waves and gives the possibility to get insight into the way attitudes are related to the declared language behaviour. The 
research questions of the paper are: what are the language attitudes of numerous post-Soviet emigration waves; how they are related to the language behaviour; and what are the differences or similarities of this wave of emigration in comparison with the earlier ones. Within the tripartite model of language attitudes, the paper analyses the overt language attitudes through the lens of the cognitive and affective dimensions combined and studies the language behaviour in different domains.

\section{Method and data}

The data analysed in this paper have been collected with the help of quantitative and qualitative methods in two large scale national research projects: "The Language of Emigrants" (2011-2013) and "Lithuanian language in diaspora: knowledge, usage, attrition" (2015-2017) ${ }^{1}$. During the first project, a large-scale online survey was conducted in 2012. It consisted of a questionnaire of 66 questions dealing with proficiency and use of languages, issues of language and identity, language attitudes and other aspects. The intention was to survey 2000 emigrants: 1000 Lithuanians who emigrated to European countries and 1000 emigrants who settled on the other continents. The respondent sample was constituted using a specifically calculated matrix based on the structure of Lithuanian diaspora on different continents and in different countries. The respondents were engaged by means of a complex network organized by a public opinion research agency ${ }^{2}$ (for more information about how the survey was conducted and the selection of respondents see Ramonienè 2015). This aim was reached with a slight surplus, and the data of 2020 individuals who participated in the survey is analysed in this paper.

During the second project a small-scale online survey was also conducted in $2017^{3}$, however, due to incomplete compatibility of the questionnaires and a much smaller sample, it will not be used for the analysis in this paper. The paper, however, uses qualitative data (see further) of the second project. As a certain limitation of the studies, it should be mentioned that despite their efforts (repetitive invitations and encouragement), the researchers had little success to engage in the study those emigrants who possibly have negative attitudes towards the Lithuanian language and Lithuania.

The number of respondents by waves and generations is presented in Table 1 . The most recent emigration wave - the post-Soviet one - has the largest number of respondents and is divided by G1 and G1+ generations, i.e. those who left Lithuania themselves (1454 respondents) and those who left during childhood together with their parents, by the decision of the parents (118 respondents). The respondents from earlier emigration waves are divided by generation: G1 (comprising some old respondents from the WWII wave and a few of those who left during the Soviet

${ }^{1}$ The first author of this paper is the principal investigator and coordinator of both projects. Both studies were funded by the State Commission of the Lithuanian language.

${ }^{2}$ The survey was carried out by UAB "SIC" in 2012, the SPSS software was used to process the data.

${ }^{3}$ The second survey was conducted by researchers of Vilnius University. 
period, 38 respondents), G1+ (who are mostly children of the WWII wave, 49 respondents), G2 (those born in the emigration country, 226 respondents) and G3 (those, whose parents were already born in emigration, 135 respondents). The largest part (78 percent) of the whole sample of respondents are emigrants of the most recent wave. The majority of them (81\%) live in European countries towards which the emigration was most intense in the last three decades. Emigrants of the earlier waves are mostly resident in North America (62\%).

Table 1

Number of respondents of Lithuanian diaspora

\begin{tabular}{|c|c|c|c|c|c|c|}
\hline \multicolumn{2}{|c|}{ Post-soviet } & \multicolumn{4}{c|}{ Earlier waves } & \multirow{2}{*}{ Total } \\
\hline G1 & G1+ & G1 & G1+ & G2 & G3 & \\
\hline 1454 & 118 & 38 & 49 & 226 & 135 & 2020 \\
\hline
\end{tabular}

During both projects, the combination of quantitative and qualitative methods was applied. Besides a quantitative survey, in-depth interviews were conducted with the respondents face-to-face or via Skype. During the first project, 177 interviews were carried out and during the second project 179 interviews were recorded with the emigrants living on various continents (Ramoniene 2015, 2019b). The interviews were conducted and transcribed by the team members of both projects. The average duration of an in-depth interview is $45 \mathrm{~min}$. Most interviews have been conducted in Lithuanian, in some there has been a switch from Lithuanian to English and some were conducted in English due to the participants' very low proficiency in Lithuanian. The in-depth interviews we collected are life story narratives that, together with the story of emigration, reveal linguistic biographies and language experiences of emigrants and their language behaviour in relation with identity construction. This paper, in addition to the analysis of the survey data, uses the interview data with regard to the in-depth processes of heritage language maintenance and loss, nuances of language attitudes, and subtle aspects of identity construction.

\section{Language attitudes towards the Lithuanian heritage language}

The multidimensional, complex phenomenon of language attitudes can play very different roles in peoples' lives; it can have an effect on their decisions and practices, the well-being of their life, career, education, luck and many other things. As presented in the Introduction, three components constituting the structure of attitudes are distinguished in language attitude studies: cognition, affect and behaviour. Even though many studies show that attitudes can determine the language behaviour of individuals and groups of people (Garrett 2010, Garrett et al. 2003), this is still debated as there are some contrasting studies indicating it is not always the case. Researchers studying the phenomena of language maintenance and shift and looking for an answer to the question why some minority groups assimilate and abandon their language while others maintain their identity and language, affirm that language attitudes are to be considered the most important factor (Bradley 2002, Wurm 2002, Pauwels 2016). It is probable that positive attitudes 
towards one's language or language variety can encourage people to use it, to maintain it and to pass it on to the next generation. And vice versa, negative language attitudes can determine a faster shift to another language. Therefore, one of the aims of investigating the language behaviour of the Lithuanian diaspora was to analyse the language attitudes towards the heritage language and to assess the importance of the Lithuanian language for those who have left Lithuania. The further investigation will concern the declared language behaviour.

The cognitive dimension is expressed in very broad beliefs and stereotypes and is reflected by an overt claim about the importance of knowing the language. The large-scale survey questionnaire had an explicit question about the importance of the Lithuanian language.

Table 2

Declared importance of knowing the Lithuanian language ${ }^{4}$

\begin{tabular}{|l|c|c|c|c|c|c|}
\hline \multirow{2}{*}{} & \multicolumn{2}{|c|}{ Post-soviet } & \multicolumn{4}{|c|}{ Earlier waves } \\
\cline { 2 - 7 } & $\mathbf{G 1}$ & $\mathbf{G 1 +}$ & $\mathbf{G 1}$ & $\mathbf{G 1 +}$ & $\mathbf{G 2}$ & $\mathbf{G 3}$ \\
\hline Very important & $84 \%$ & $80 \%$ & $84 \%$ & $88 \%$ & $74 \%$ & $56 \%$ \\
\hline More important than unimportant & $12 \%$ & $18 \%$ & $13 \%$ & $12 \%$ & $17 \%$ & $24 \%$ \\
\hline More unimportant than important & $2 \%$ & $3 \%$ & $3 \%$ & - & $7 \%$ & $14 \%$ \\
\hline Not important at all & $1 \%$ & - & - & - & $1 \%$ & $6 \%$ \\
\hline
\end{tabular}

As can be seen in Table 2, the declared importance of knowing the Lithuanian language is very high in all the waves. Most of the G1 and G1+ respondents affirm that the Lithuanian heritage language is indeed important for them. As much as 84 percent of G1 respondents of all waves stated that it is very important for them. Another 12-13 percent stated that it is more important than unimportant for them. While those who consider Lithuanian of little importance were only few: 2-3 percent more unimportant than important and only less than 1 percent from the most recent wave responded it was not important to them at all, however, none of the G1 from the earlier waves chose this answer. The situation is quite similar for the G1+, but with the G2 one can note the shift starting to take place. Less G2 and G3 respondents consider it of high importance. and there are notably more those who do not consider knowing Lithuanian to be important.

There is proof that some language attitudes, as well as the language itself, are acquired very early (Garrett et al. 2003) and that attitudes acquired early tend to remain rather stable and endure in the lifespan (Sears 1983). At the start of the formation of language attitudes, parents and the family can have a big influence (Garrett 2010). Many scholars recognize that the role of the family is the most important for the maintenance or loss of the heritage language (Fishman 1991, Pauwels 2016, Haque 2019). Family is seen as the critical domain where the language is either maintained or lost. As Spolsky (2012: 4) puts it: "The loss of natural intergenerational transmission was recognised as the key marker of

\footnotetext{
${ }^{4}$ Chi-squared tests have been conducted and the light grey cells indicate statistically significant differences $(p<0.05)$ here and in the following tables.
} 
language loss, and occurred within the family." The importance of knowing Lithuanian is well described by a G1+ woman of the WWII emigration wave, who emphasizes the beliefs as one of the most important reasons for the maintenance of Lithuanian (example 1).

(1) There are those who think what sense does it make, we will never return to that Lithuania, but anyway, even if you never return to Lithuania, the language is the oldest language alive in the word, it's a kind of honour to know it, not necessarily very well. We could never tell our children it was practical because we were really deeply convinced that Lithuania will never be free, but we would always say that it's an honour. You have to maintain the language because we don't know what is going on there, the russification is very strong there, so it was mainly for reasons like this that we maintained the language in our home. (USA, W68, G1+) ${ }^{5}$

Table 3

Most precious and most useful languages

\begin{tabular}{|l|l|c|c|c|c|c|c|}
\hline \multicolumn{2}{|c|}{} & \multicolumn{2}{|c|}{ Post-Soviet } & \multicolumn{4}{|c|}{ Earlier waves } \\
\cline { 3 - 8 } \multicolumn{2}{|c|}{} & G1 & G1+ & G1 & G1+ & G2 & G3 \\
\hline \multirow{2}{*}{$\begin{array}{l}\text { Which language seems } \\
\text { to be the most precious }\end{array}$} & Lithuanian & $86 \%$ & $89 \%$ & $95 \%$ & $94 \%$ & $80 \%$ & $65 \%$ \\
\cline { 2 - 8 } & English & $3 \%$ & $5 \%$ & $3 \%$ & $2 \%$ & $4 \%$ & $9 \%$ \\
\cline { 2 - 8 } & Other & $12 \%$ & $6 \%$ & $3 \%$ & $4 \%$ & $15 \%$ & $26 \%$ \\
\hline \multirow{2}{*}{$\begin{array}{l}\text { Which language seems } \\
\text { to be the most useful }\end{array}$} & Lithuanian & $6 \%$ & $3 \%$ & $3 \%$ & $4 \%$ & $4 \%$ & $4 \%$ \\
\cline { 2 - 8 } & English & $82 \%$ & $90 \%$ & $76 \%$ & $90 \%$ & $87 \%$ & $79 \%$ \\
\cline { 2 - 8 } & Other & $12 \%$ & $8 \%$ & $21 \%$ & $6 \%$ & $9 \%$ & $16 \%$ \\
\hline
\end{tabular}

It has already been mentioned that attitudes are affective because they involve feelings about the attitude object. The emotional language attitudes' dimension of Lithuanian emigrants was revealed by the answers to the survey question: What language is the most precious, the dearest to you? When responding to this question, a great majority of all the respondents indicated the Lithuanian language. A high ( $85-89 \%$ ) percentage of post-Soviet wave G1 and G1+ respondents declared it as the most precious, however, even more of the earlier waves' G1 and G1+ gave the same answer. The emotional connection to Lithuanian as the most precious language is slightly lower in the G2 (80\%) and notably lower in G3 (65\%). In Table 3 we presented for contrast the answers to the question which language is considered to be most useful. The data shows a nearly inverted picture with the English language indicated as the most useful by an overwhelming majority of respondents (76-90\%) and Lithuanian as of very little usefulness (2-6\%). The only ones who see Lithuanian as useful at least to some extent are the G1 of the postSoviet wave, quite likely due to the maintained active contacts in Lithuania.

The relationship of the Lithuanian heritage language with special positive emotions was mentioned by many participants during the qualitative interviews. Example 2 presents an extract where a participant from the post-Soviet emigration

${ }^{5}$ In the brackets the country, sex (W - women, $\mathrm{M}$ - man), age and generation of emigration of the respondent is indicated. The interviews were carried out in Lithuanian. 
wave describes the communicational space where Lithuanian is spoken with friends in the emigration context as a "little Lithuania":

(2) When we all start speaking Lithuanian, it's like a little Lithuania... nice. (Germany, W39, G1)

Another participant who lives in Italy (example 3) also expresses special emotions related to language. In her family, she usually speaks Lithuanian with her two children and an Italian husband who knows Lithuanian, sometimes codeswitches, but the communication in Lithuanian is associated with the most beautiful feelings. The woman emphasizes that she can express the most subtle emotions, even when writing SMS messages to her children, only in her native Lithuanian language:

(3) It was possible (to speak in the family) in various ways but... but it is the best, the most intimate feeling is when we speak Lithuanian. $<\ldots>$ When you want to say something really from the heart, it is only in Lithuanian, the most subtle feelings. (Italy, W58, G1)

A young woman living in France also emphasizes that she only calls her children with Lithuanian diminutive names, not French, she associates it with her own childhood, with the deep emotions, "from the heart", she only sings Lithuanian lullabies (example 4).

(4) $R^{6}$ : And in the beginning, when the first (child) was born, the first girl?

P: Yes.

R: Did you speak Lithuanian?

P: Yes, all the time and all the diminutives. For instance, I cannot say some

French names as diminutives. They come from deep inside, from the heart, from what I myself heard when I was little. I cannot say some diminutive names in French. To a baby, the lullabies were always in Lithuanian. Some kind of secret mother and child world. (France, W32, G1)

Self-perception that forms from childhood into adolescence creates the sense of identity and is later in life strongly associated with emotions. The aspect of the identity of the Lithuanian emigrants was studied based on the data of the Lithuanian diaspora research projects (Jakaitė-Bulbukienè 2015, Vilkienè 2015, 2019, Ramoniene 2019b). These studies show that the attitude of the post-Soviet emigration wave towards Lithuania is heterogeneous (Jakaité-Bulbukienè 2015); it is strongly affected by emotions and related to emigration stories. Quite frequently Lithuanians of the current emigration wave prioritize the integration into the society of the new country rather than the maintenance of Lithuanian identity (Vilkiene 2019). However, when asked about how they feel when thinking about themselves, about their own identity (see Table 4), $72 \%$ of the G1 of the post-Soviet emigration wave state that they feel Lithuanian and only $4 \%$ identify themselves with the new country of residence. There is much less certainty, however, among the post-Soviet

${ }^{6} \mathrm{R}$ indicates researcher, and $\mathrm{P}$ participant. 
$\mathrm{G} 1+$, that is young people who have moved to another country by the decision of the parents, and even though half of them (55\%) still feel Lithuanian, this is the generation where quite a few consider themselves not to belong specifically to any country or even a continent as $13 \%$ of them declared to feel "world citizens".

Table 4

Declared identity of Lithuanian emigrants

\begin{tabular}{|l|c|c|c|c|c|c|}
\hline & \multicolumn{2}{|c|}{ Post-soviet } & \multicolumn{4}{|c|}{ Earlier waves } \\
\cline { 2 - 7 } & G1 & G1+ & G1 & G1+ & G2 & G3 \\
\hline Lithuanian & $72 \%$ & $55 \%$ & $74 \%$ & $61 \%$ & $37 \%$ & $24 \%$ \\
\hline Half-Lithuanian and half another nationality & $7 \%$ & $15 \%$ & $13 \%$ & $27 \%$ & $46 \%$ & $40 \%$ \\
\hline $\begin{array}{l}\text { A person from a country where he / she lives } \\
\text { most of his / her time }\end{array}$ & $4 \%$ & $5 \%$ & $11 \%$ & $6 \%$ & $10 \%$ & $15 \%$ \\
\hline $\begin{array}{l}\text { A person from a continent where he / she } \\
\text { lives (e.g. European, American) }\end{array}$ & $8 \%$ & $9 \%$ & - & $2 \%$ & $4 \%$ & $11 \%$ \\
\hline A world citizen & $8 \%$ & $13 \%$ & $3 \%$ & $2 \%$ & $2 \%$ & $7 \%$ \\
\hline Other: & $0,1 \%$ & - & - & - & $0,4 \%$ & $0,7 \%$ \\
\hline I do not know, it is hard to tell & $2 \%$ & $3 \%$ & - & $2 \%$ & $2 \%$ & $2 \%$ \\
\hline
\end{tabular}

During the in-depth interviews, many study participants have expressed their emotional connection with Lithuania, even though they left the country by their own decision. A young woman living in Germany, when talking about her son's identity, was worried that it would be very hard for her if her son renounced the Lithuanian identity (example 5):

(5) If the child said that he is a German, it would be terrible for me. Terrible. $<\ldots>$ both of us (with the husband) are Lithuanian and we love Lithuania, and if the child felt German, it would be very hard. (Germany, W 35, G1)

When asked what country they consider their own, many participants emphasized that it is only Lithuania that they consider their true home (examples 6-8). Therefore, the identification with Lithuania as one's own country is a clear characteristic of the participants of the study who belong to the most recent emigration wave.

(6) My country is only Lithuania. For me America is definitely not my country. (USA, W45, G1)

(7) Home, my heart, my everything, my home is in Lithuania. (Germany, W40, G1)

(8) My country is Lithuania. The country of my children is France. (France, W32, G1)

From the data analysis it seems evident that considering the cognitive and affective dimensions, the attitudes towards Lithuania and the Lithuanian language are very positive. The beliefs have a strong affective aspect and all the emotions related to whatever is Lithuanian are the most favourable. However, the qualitative data seems to give insight that the post-Soviet G1 emigrants are strongly convinced and have positive attitudes about Lithuania themselves but might not be much concerned about educating their children in the same manner. The emigrants from the earlier waves, especially those who left Lithuania because of WWII, have made 
a great and specific effort into the Lithuanian bringing up of their children, so much that the G1+ imitated this when educating their own offsprings (this is in a way echoed in the attitudes of G2 and G3). The following section will look into the declared language behaviour and see whether the positive attitudes seen in this section determine the language practice.

\section{Uses of the Lithuanian language}

\subsection{General and personal use}

Fishman's (1991) multi-generational model for language maintenance and shift shows how a language typically exists in emigration: the first generation emigrate knowing their own language and more or less acquire the language of the new environment, the second generation more or less acquire the home language and acquire the language of the environment well, while the third generation know the language of the environment well but rarely learn the heritage language. This is reflected in our data as first generation Lithuanian emigrants use Lithuanian in the country of their residence. Table 5 presents answers to the general question about Lithuanian language use in the country where they live. The data show that 90 percent of post-Soviet G1 (and 87\% of earlier waves' G1) respondents affirm they use Lithuanian. The G1+ respondents from all the waves use Lithuanian in the country even more. And even if the G2 percentage is rather high $(80 \%)$, an important decrease can be seen in the third generation (47\%). Therefore, our data generally show the same tendency as stated by Fishman, however, the high percentage of use of Lithuanian in the country of residence by the G2 is most probably the effect of their efforts to maintain the Lithuanian heritage language for younger generations and thus a relatively high percent also among the G3.

Table 5

General use of Lithuanian in the country of residence

\begin{tabular}{|c|c|c|c|c|c|}
\hline \multicolumn{2}{|c|}{ Post-Soviet } & \multicolumn{4}{c|}{ Earlier waves } \\
\hline G1 & G1+ & G1 & G1+ & G2 & G3 \\
\hline $90 \%$ & $94 \%$ & $87 \%$ & $98 \%$ & $80 \%$ & $47 \%$ \\
\hline
\end{tabular}

The emigrants of the most recent wave are often not much detached from the life in Lithuania: they follow Lithuanian media, read books, etc. A big part of the post-Soviet G1 emigrants declare that they are interested in the life and culture of Lithuania (66\%) and they identify themselves with Lithuanian history $(80 \%)$. It is therefore not surprising that they affirm that they use not only the oral but also the written Lithuanian language (see Figure 1). The respondents declare that they often or at least sometimes read books (in total 95\%), press (in total 91\%), to write in Lithuanian (in total 98\%), to browse the internet (in total 96\%) in Lithuanian. The post-Soviet G1+ respondents' answers are slightly lower but also rather high in all of these activities. Among the earlier waves' emigrants, the G1 and G1+ respondents also use written Lithuanian to a high percent with the gradual decrease in G2 and G3. This, however, shows the G2 and G3 of the earlier waves have the competence to use written Lithuanian. 


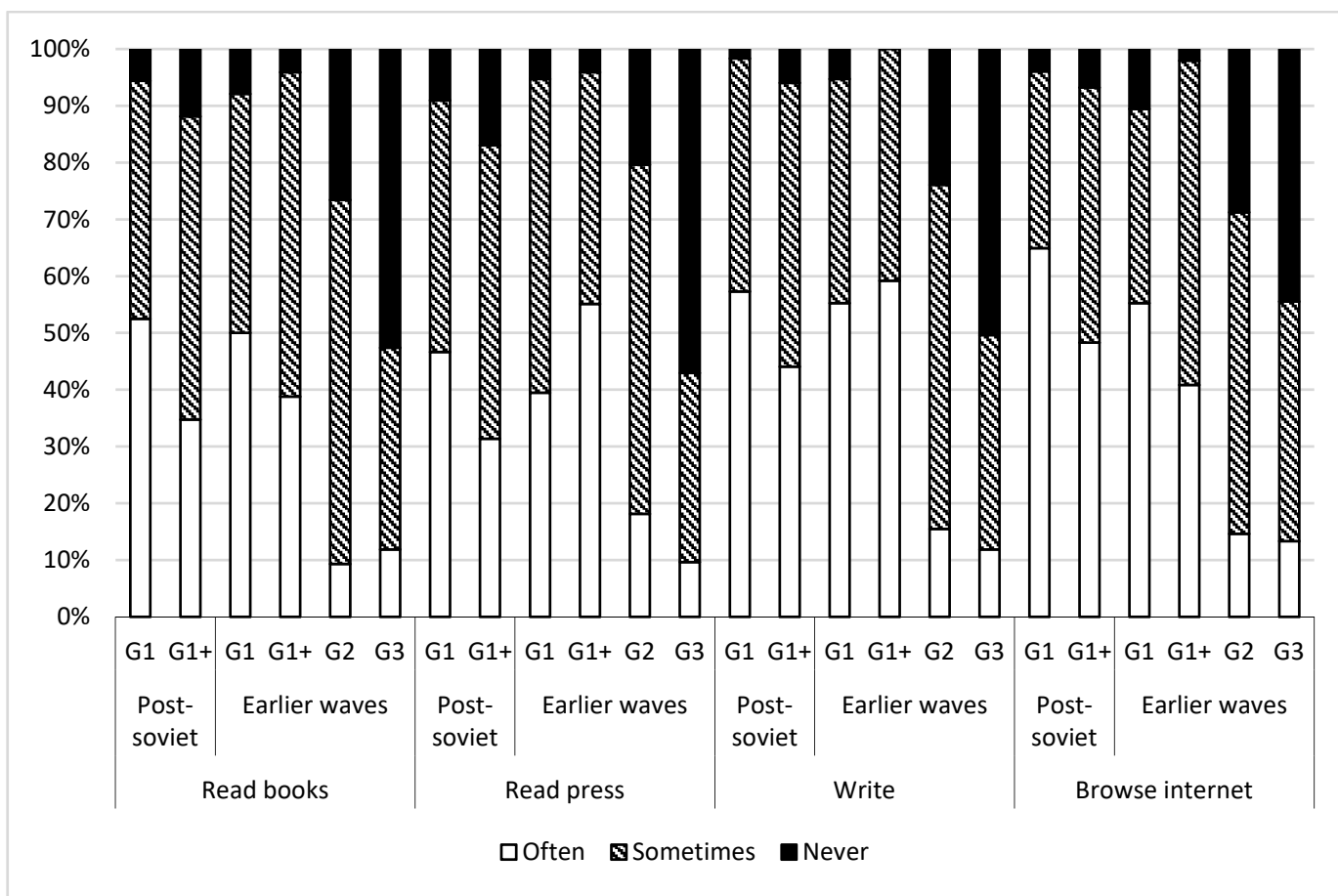

Figure 1. Use of written Lithuanian

Another important aspect of language use is the inner language of a person. It is quite natural that Lithuanian is the inner language of a regular post-Soviet G1 emigrant: $99 \%$ of them affirm that they think in Lithuanian, $98 \%$ state they count in Lithuanian. During the in-depth interviews, some emigrants who spend most of their time in the language of the immigration country said their primary language of thought is Lithuanian. One interviewed scholar, for example, who did not live in Lithuania for 12 years, who has worked in different foreign countries, who now lives in Germany and uses German or English at work, associates only Lithuanian with his own thinking and brain activity (example 9):

(9) $R$ : And in what language do you think?

P: I count in Lithuanian, I think in Lithuanian... it is, how to say, burned into the brain already.

(Germany, M35, G1)

Another respondent living in Canada states that she is conscious of the fact that Lithuanian is the language of her dreams, the base of her thinking (example 10):

(10) P: (Lithuanian for me is) the language of emotions, the language of tiredness, when the brain does not want to think anything anymore, because English for me is work, it is work for me.

$R$ : So in what language do you think?

P: Well, it depends: I especially catch myself when I write. I write (in English) and then I realize that I am thinking in Lithuanian $<\ldots>$ Dream? Only in Lithuanian. (Canada, W59, G1) 


\subsection{Use of Lithuanian in different domains}

When analysing the use of Lithuanian in various domains, important differences can be seen in the data of different emigration generations. The order of the domains where Lithuanian is used differs the most when the post-Soviet emigrants are compared with the emigrants of the previous generations. If we look at the top three domains, we will see that the order and proportions indicated of the post-Soviet and the earlier waves' emigrants are quite different (see Table 6). For all post-Soviet emigrants, the most frequent domain of the Lithuanian language use is the home ( $77 \%$ for $\mathrm{G} 1,90 \%$ for $\mathrm{G} 1+$ respondents). For them the community is in the second place ( $60 \%$ for G1, $56 \%$ for G1+ respondents). The third place, however, differs for the post-Soviet G1 and G1+: use at work and with friends is equally distributed for the G1 (23\%), while the G1+ use Lithuanian a lot in semi-public domains (cafes, shops etc., 22\%).

Table 6

Use of Lithuanian in different domains ${ }^{7}$

\begin{tabular}{|l|c|c|c|c|c|c|}
\hline & \multicolumn{2}{|c|}{ Post-soviet } & \multicolumn{4}{|c|}{ Earlier waves } \\
\hline & $\mathbf{G 1}$ & $\mathbf{G 1 +}$ & $\mathbf{G 1}$ & $\mathbf{G 1 +}$ & $\mathbf{G 2}$ & $\mathbf{G 3}$ \\
\hline At home & $77 \%$ & $90 \%$ & $70 \%$ & $79 \%$ & $71 \%$ & $64 \%$ \\
\hline $\begin{array}{l}\text { At the hairdresser's, in cafes, shops, } \\
\text { and other similar places }\end{array}$ & $11 \%$ & $22 \%$ & $3 \%$ & $4 \%$ & $11 \%$ & $6 \%$ \\
\hline At work & $23 \%$ & $16 \%$ & $18 \%$ & $4 \%$ & $8 \%$ & $9 \%$ \\
\hline At school, university & $4 \%$ & $10 \%$ & $3 \%$ & $2 \%$ & $2 \%$ & $5 \%$ \\
\hline In the meetings of the Lithuanian community & $60 \%$ & $56 \%$ & $76 \%$ & $94 \%$ & $90 \%$ & $84 \%$ \\
\hline In church & $11 \%$ & $16 \%$ & $39 \%$ & $44 \%$ & $51 \%$ & $41 \%$ \\
\hline With friends & $23 \%$ & $11 \%$ & $9 \%$ & $44 \%$ & $23 \%$ & $13 \%$ \\
\hline
\end{tabular}

These domains come in different order according to the frequency of use by emigrants of the earlier waves. In the communication of all the generations, the heritage language is used firstly not at home but in the community (76-94\%). The home domain is in the second place, where $64-79 \%$ of all the generations claim to use Lithuanian. The third place is occupied by a domain that does not appear in the top three of the post-Soviet wave domains, that is the church where $39-51 \%$ of the respondents from the earlier waves claim to use Lithuanian. In the following section, these top domains will be analysed separately.

\subsubsection{Home domain}

It is natural that the heritage language is used in the home domain of emigrants of the first generation. If both parents speak the same heritage language, the communication at home in that language is often chosen as the main or at least the desired communicative strategy (Pauwels 2016). This is confirmed by our data. Out

${ }^{7}$ Multiple answers were possible, therefore the percentage indicates the part of total in that group. 
of all Lithuanian emigrants surveyed, 50\% confirmed they lived in mono-ethnic Lithuanian families. Therefore, the frequent use of Lithuanian in the home domain is not surprising.

However, to maintain a heritage language in a mixed family, when parents belong to a different ethnolinguistic group, especially where one parent is a speaker of the language of the immigration country, is much more difficult. According to our data, $67 \%$ of the G2 and as much as $86 \%$ of G3 emigrants of the previous emigration waves live in mixed families, therefore, they use less Lithuanian both in general and in their families. As can be seen in Table 6,71\% of G2 and 64\% of G3 emigrants affirm they use Lithuanian at home and this is the second most popular domain they use Lithuanian in.

Nevertheless, it is worthwhile looking into the question of the Lithuanian language maintenance in G2 and G3's family language policy that has already been somewhat analysed. Previous studies found that quite a large part of the second wave of Lithuanian emigrants (Jakaitė-Bulbukienè 2015, Ramonienè 2019a, Vilkiene 2019), the WWII wave, had formed a rather successful family language policy and management. so that they were able to pass on the Lithuanian language to the younger generations, not only to the second but often also to the third or even the fourth generation. The desire to maintain the Lithuanian identity and Lithuanian language by the members of this emigration wave who called themselves not emigrants but war refugees and were hoping to come back to Lithuania soon, were very clear and strong. Many families of this emigration wave formed their home environment as completely Lithuanian, where only Lithuanian is spoken. This rather strict language management helped them to maintain the heritage language because, as our participants state, at home it was often forbidden to speak other languages than Lithuanian (example 11).

(11) In our house there was a very clear understanding, that not even a word here, it's Lithuania here. $<\ldots>$ when I came back home, the door closes and there is Lithuanian language here. Here is Lithuania, there is a Lithuanian flag and this is our territory and that's how we behave here. (USA, W68, G1+)

The interview data show that language maintenance for the emigrants of this generation is understood as an indispensable duty, as one G3 informant who lives in the USA puts it (example 12):

(12) (to maintain Lithuanian) becomes a kind of obligation. Because if I stop, what will happen? <...> I don't want to be the one that stops it in our family, you know. It's a responsibility almost, that you have to maintain... (USA, W45, G3)

During the in-depth interviews quite a few informants of G2 expressed gratitude to their parents for applying a strict language policy as a result of which they have maintained the Lithuanian language as an enormous gift (example 13): 
(13) This is completely the merit of the parents (that I know Lithuanian well). $<\ldots>$ My parents' hand was strict. $<\ldots>$ when I finally realized, that all of this was really only because of their decision that the children will speak Lithuanian. <...> I really appreciate my parents, that they gave me the language as a gift. (USA, W63, G2)

When analysing the data of the most recent post-soviet emigration wave, one can find a different attitude to passing on the Lithuanian language to the younger generations. In general, it seems that the Lithuanian language maintenance and passing it on to the children and grandchildren seems appealing as $92 \%$ of G1 respondents answered positively to the question Would you like your future generations (children, grandchildren, etc.) to know Lithuanian language. However, many of them expressed unwillingness to undertake an active, strict family language policy. Some participants also emphasized the fact that the problems of emigrant life in the new country do not allow to concentrate, to dedicate a lot of time, to engage in a specific way in teaching the heritage language to the children (examples 14, 15).

(14) You know, we did not take some drastic measures (to teach Lithuanian) $<\ldots>$ well that state when you emigrate to another country and you have to start a new life, there are so many simple things that we have to do here. (USA, W45, G1)

(15) But somehow life goes on, there are so many things that need to be done, that sometimes things like thinking in what language should I speak to the child fall into the second... into the second place. (Canada, M35, G1)

Sometimes they indicate that it is very important for children themselves to decide to learn Lithuanian, that they wouldn't be forced to learn Lithuanian, that it should not be made too stressful for children (example 16), and that life in emigration naturally forces the children to switch to the language of the country of residence (example 17). Knowing Lithuanian is sometimes valued more for pragmatic reasons, so that the children would know one more language to be able to communicate with grandparents and other relatives in Lithuanian, but not so much for maintaining the Lithuanian identity. In cases of unsuccessful attempts to teach their child Lithuanian or when seeing the unwillingness or passivity of the children, they often abandon their decision and switch to speaking to their children in the language of the country of residence (also see Hilbig 2020).

(16) It would be nice if they (children, grandchildren) knew Lithuanian, but yes, it's not important for me. <...> It would be nice. Because our family roots are somewhere in Lithuania $<\ldots>$ I want to allow my son to decide for himself what language should he learn because it's important for me that my son was a child, because nowadays the children are especially from the young age forced into schools, taught languages, loaded with stuff, that they don't have time to be children. (Germany, M39, G1) 
(17) What should one do if they (children) speak German to each other. We have talked about it (with the wife). And we still reached a conclusion that it is a natural thing, because we cannot change this in any way. Because we live here, they grow here, they communicate here, we cannot change them in some artificial manner, because they live not in Lithuania. (Germany, M35, G1)

\subsubsection{Community domain}

According to the frequency of use of Lithuanian, the community has an important place in the lives of emigrants. Our survey data show that this domain is particularly important to earlier waves' G1+, G2 and G3 emigrants, where it occupies the first place according to the use of the heritage language and precedes home domain in importance. As presented in Table 6, 94\% of G1+, 90\% of G2 and $84 \%$ of G3 emigrants claim to use Lithuanian for communication in the community. It is important to emphasize once more that the most of the earlier waves' $\mathrm{G} 1+$, the G2 and G3 respondents who participated in the survey, are children and grandchildren of WWII refugees. The community had and still has a particularly important role in the life of the emigrants of this wave. This can be seen from the in-depth interviews where the informants of G2 and G3 spoke about a constant participation in some kind of Lithuanian activity now and since their childhood, where they used to spend time together with their parents, siblings and Lithuanian friends (examples 18, 19). This was the way to maintain Lithuanian identity, to expand the possibilities for the young generation to speak Lithuanian not only at home but also outside the home domain:

(18) I grew up in a very typical Lithuanian family. It means that there were Lithuanian activities during the whole week. Church on Sunday, school on Saturday, national dances on Thursday. (Canada, W48, G2)

(19) We have so much here in Toronto: churches, and I work in a Lithuanian school now <...> and I sing in a choir. Almost everything that we do after work and on weekends is with the Lithuanian community. (Canada, M31, G3)

The use of Lithuanian in the community by post-Soviet emigrants is also rather important but not as much as it is important for the emigrants of the earlier waves. As our survey data show, this domain is in the second position after the home domain, according to the frequency of use of the Lithuanian language for the postSoviet wave. $60 \%$ of the surveyed G1 and $56 \%$ of G1+ respondents claim to use Lithuanian in the community.

However, it should be mentioned that the participation of the most recent emigrants in the activities of Lithuanian communities differs a lot from those in the previous emigration waves. The new emigrants are a lot less likely to join the life of the communities. Table 7 shows that post-Soviet G1 and G1+ emigrants participate by far less in the activities of the community, as compared to the emigrants of the earlier waves. There are only $11 \%$ of post-Soviet G1 (and $15 \% \mathrm{G} 1+$ ) emigrants who state to actively participate in the activity of the 
Lithuanian community in their country of residence, while for the generations of the earlier emigration waves this number is between 33 and 59\%. A considerable part of the post-Soviet survey participants $(16 \% \mathrm{G} 1$ and $14 \% \mathrm{G} 1+)$ responded they do not want or do not feel the need to participate in the life of the Lithuanian community, while opinions of this type were not found at all in the earlier waves' G1+ and far less frequent in G2 (3\%) and G3 (only 1\%). Therefore, our data confirms the attitude towards community difference noted by others concerning the new post-Soviet emigration wave. Other diaspora generations had a strong characteristic of creating Lithuanian associations and participating in their activities. In the post-Soviet emigration wave, however, there are no evident tendencies of solidarity associations (Aleksandravičius 2013).

Table 7

Participation in the activities of Lithuanian communities

\begin{tabular}{|l|c|c|c|c|c|c|}
\hline \multirow{2}{*}{} & \multicolumn{2}{|c|}{ Post-Soviet } & \multicolumn{3}{|c|}{ Earlier waves } \\
\cline { 2 - 7 } & $\mathbf{G 1}$ & $\mathbf{G 1 +}$ & $\mathbf{G 1}$ & $\mathbf{G 1 +}$ & $\mathbf{G 2}$ & $\mathbf{G 3}$ \\
\hline Yes, I am actively involved & $11 \%$ & $15 \%$ & $34 \%$ & $59 \%$ & $45 \%$ & $33 \%$ \\
\hline I take part when I can, sometimes & $36 \%$ & $36 \%$ & $34 \%$ & $29 \%$ & $35 \%$ & $41 \%$ \\
\hline $\begin{array}{l}\text { I do not take part because the Lithuanian } \\
\text { community is not very active }\end{array}$ & $9 \%$ & $12 \%$ & $8 \%$ & $4 \%$ & $6 \%$ & $13 \%$ \\
\hline $\begin{array}{l}\text { I do not take part because of objective } \\
\text { reasons (it is too far, I do not have time, etc.) }\end{array}$ & $28 \%$ & $19 \%$ & $13 \%$ & $6 \%$ & $11 \%$ & $11 \%$ \\
\hline $\begin{array}{l}\text { I do not take part because I do not find } \\
\text { it interesting or useful }\end{array}$ & $16 \%$ & $14 \%$ & $8 \%$ & - & $3 \%$ & $1 \%$ \\
\hline Other & $1 \%$ & $3 \%$ & $3 \%$ & $2 \%$ & $1 \%$ & $2 \%$ \\
\hline
\end{tabular}

However, one cannot make the claim that community activities or the communication in Lithuanian during these activities is completely foreign to Lithuanian emigrants of the current wave. Data of the in-depth interviews shows that the emigrants of the most recent wave join the previously established communities and Lithuanian schools not as often as G2 and G3 emigrants, but occasionally participate in the events (this can also be inferred from the $36 \%$ of post-Soviet G1 and G1+ who claim to participate sometimes, when they are able to), sometimes even establish new communities in countries that did not have communities previously (example 20), learn from the previous waves and organize new associations (example 21), create Facebook groups (example 22) where they feel to live a different - Lithuanian - life and thus satisfy their wish to communicate in Lithuanian (also see Gudavičienè 2019).

(20) I participate (in the activity of Oslo Lithuanian community). I also used to be on the board. $<\ldots>$ We used to organize, I sat in a jury for a few years, fine reading competitions and embassy events. (Norway, W46, G1)

(21) Our friends are mostly Lithuanian, we have created a women's club, “Alateja”, we (speak) Lithuanian there. We practically live a double life. (USA, W45, G1)

(22) We have created a group now. As I live in Lyon, so I created a Facebook group Lithuanians of Lyon, so we now, well, it works positively. At least to me personally, because I have someone to talk to. (France, W32, G1) 


\subsubsection{Friendship domain}

One more domain worth analysing when looking at the different waves of emigration is friendship, occupying the third place of communication in Lithuanian according to frequency among post-Soviet emigrants, together with the work domain. As presented in Table 6, as much as 44\% of the WWII refugees' children generation use Lithuanian to talk to their friends, whereas $23 \%$ of both post-Soviet G1 and earlier waves' G2 respondents affirm to use Lithuanian when speaking to friends. The use of Lithuanian in these relationships among post-Soviet G1+ and G3 emigrants is much lower: only 11 and $13 \%$ respectively.

How can this use of Lithuanian in the friendship domain be explained? The same proportions of Lithuanian language use found in the lives of post-Soviet G1 and earlier waves' G2 emigrants seem to be determined by dissimilar and rather different reasons.

In general, emigrants of the first generation tend to bond with other Lithuanian speaking emigrants often because they feel a psychological discomfort when living in a foreign country. As perceived in the in-depth interviews, the emigrants of the most recent wave do not feel "at home" themselves in the new country (examples 23, 24) and seldom become friends with locals. Circles of new friends of the last emigration wave are forming in various countries, and people speak Lithuanian there. As much as $37 \%$ of the post-Soviet G1 (32\% G1+) emigrants who participated in the survey stated their preference of Lithuanian speaking friends:

(23) No, here (in Canada) I do not belong. No way (I can be considered) as belonging here. $<\ldots>$ I will never belong here. (Canada Mot 59, G1)

(24) I'm telling you, at the age of fifty coming here, to integrate here it was, it is difficult for me. And I go there (to Lithuania) and my soul sings there. Because here it still is foreign. (USA, W65, G1)

The post-Soviet G1+ in the friendship domain seem to be more similar to the G3 than to other generations. It would seem the post-Soviet G1+, who emigrated by the decision of their parents, make an effort to integrate into the new environment as best as they can by making friends mostly with the local people.

The friendship domain can be seen from a slightly different perspective when looking at the G2 emigrants, where the communication in Lithuanian with friends is in the fourth position and constitutes a relatively large part of the entire communication in Lithuanian: $23 \%$. The Lithuanian friendships of this generation are closely connected with the already mentioned Lithuanian communities and with the aspiration of the parents to educate their children to be Lithuanian. Especially the Second World War refugees took great care of Lithuanian friendships of their children because they understood that this can be the foundation for the formation of Lithuanian identity. They created social networks for their younger generation where they could form friendships that many maintained during their entire life. More than one emigrant has emphasized the significance of friendships in relation 
to Lithuanian language maintenance, Lithuanian identity and personal psychological comfort (examples 25, 26, 27):

(25) Without Lithuanian friends I would be very lonely. (USA, W65, G2)

(26) When I was growing up, that parish and all those friends: those scouts, those school friends - they were family. And our parents were all friends and the children were growing up together and they were friends. And now they are my family, they are godparents of children. And, you know, there is a community. If those were not there, it would be very bad. And maybe not because of the Lithuanian identity but maybe because of the soul of a human and how it grows. I think that Americans don't have such relationships that last since birth. You know, and we are Lithuanians. I know my friends from, you know, when we were three years old and we still have something to talk about, every day. It's like that because we are like family and we grew up together in the parish. I think that is very important. If there are some problems in life or if while you go through all those teenager years, you can be further away and take a bad road. You have this other support system, you have another group, where you can be accepted and looked after. (USA, W45, G3)

(27) It is in those organizations where real friendships form, of the kind that last a lifetime. (Canada, W66, G2)

\subsubsection{Church domain}

One more domain where the communication in Lithuanian by post-Soviet emigrants differ notably from emigrants of the earlier waves, is the church, which occupies the third place according to the frequency of use of Lithuanian in different domains in the life of earlier wave emigrants (Table 6). $44 \%$ of earlier wave G1+, $51 \%$ of G2 and $41 \%$ of G3 respondents affirm that they speak Lithuanian in church. This domain and usage of Lithuanian in church is far less important to the postSoviet emigrants, only $11 \%$ G1 (16\% G1+) state that they use Lithuanian language in church. More than in church they use Lithuanian with friends, at work, speak Lithuanian in shops and other service domains (11\% for G1 and surprising $22 \%$ for $\mathrm{G} 1+$ ). From the interviews of G2 and G3 emigrants it can be understood that in their life the Lithuanian church is almost a synonym of the Lithuanian community. This is due to the fact that in the life of the communities of the previous Lithuanian emigration waves, the church and other Catholic organizations were a very important part, directly connected with the Lithuanian identity and its maintenance, as well as the use of the Lithuanian language (examples 28, 29), whereas the emigrants of the most recent post-Soviet emigration wave, having experienced a lot of atheist education in Soviet Lithuania, are far less participating in church life in general. This new wave emigrants' behaviour is noticed also by the emigrants of the previous waves (examples 30,31 ). Therefore, it is natural that the church domain is a lot less associated with the Lithuanian language and its use for the emigrants of the post-Soviet emigration wave. 
(28) The church was very important, it was like the centre, we would all meet there with our friends. And we would keep friends separately, those who were English friends, who were school friends, and then there were real friends, who were Lithuanian. And usually on weekends we would spend time only with Lithuanians. (Canada, W66, G2)

(29) Our friends $<\ldots>$ are almost exclusively Lithuanian. And for now we are very attached to the parish, so we go there $<\ldots>$ forty miles one way. (USA, W76, G1+)

(30) The church is not very important for them. (USA, W65, G2)

(31) Now with the third-wavers I see different aspects. $<\ldots>$ Our teachers, for example, many of them are already from the third-wavers, and they manage to balance both lives very well, while others have disappeared without even passing by the parish. And I think that this is a lack of faith or even hatred towards the faith that pushes them away from the parish, from everything that has something in common with the parish $<\ldots>$ it seems to me that this hatred, that they are repelled by what is religious. (USA, W68, G1+)

\section{Discussion and conclusions}

Summing up, the Lithuanian language is used by the majority (above 90\%) of Lithuanians of the new emigration wave in various domains. They speak Lithuanian at home, in Lithuanian communities, with friends and elsewhere, they read, write, browse the internet in Lithuanian, and for many of them Lithuanian is their inner language in which they think, count and dream. However, when comparing this to emigrants from the previous emigration waves, a difference of use of Lithuanian can be noted in some domains. G2 and G3 Lithuanian emigrants usually speak Lithuanian in Lithuanian communities; the home domain is in the second place and the church, according to the frequency of use of Lithuanian, is in the third place. For Lithuanians of the post-Soviet emigration wave, the most frequent domain for the use of Lithuanian is home; the second domain is community, whereas work and friends are in the third position. The characteristics of the language behaviour of the new emigration wave are related to their minor tendency towards socialization, with the aspiration of the first emigration generation for quick integration to the society of the new country. Lithuanians of the post-Soviet emigration wave tend to support a less strict family language policy at home regarding their heritage language maintenance than political emigrants who left Lithuania at the end of WWII. Most of the post-Soviet emigrants would like their children and grandchildren to know Lithuanian, but they are less likely to put a lot of effort into the maintenance of the Lithuanian language and identity, as compared to the emigrants of the previous wave. The new emigrants have different priorities for their emigrant life: to become stable in the new country, to create a comfortable, easier, good life for the children, aspects exactly characteristic of the emigrants of economic nature.

Having analysed the cognitive and affective dimensions of language attitudes of the post-Soviet emigrants, we can state that both beliefs and language-related 
emotions regarding Lithuanian are very positive; in this respect this emigration wave does not differ much from the earlier waves. Steadfast beliefs about the value of the Lithuanian language itself and the bond with Lithuanian history is shared by all those of Lithuanian descent. For most of the new wave emigrants, Lithuania remains their own country, emotionally closer than the new country that has accepted them, and the Lithuanian language remains the dearest, the most precious language.

The focus of our attention and the major difference is found in the behavioural dimension. The positive cognitive and affective components of attitudes do not seem to have a sufficiently strong effect on the declared behaviour. Even in the overt expression of attitudes they declare different priorities, and the economic and everyday well-being is put in the first place. They do use the Lithuanian language in situations where it is more convenient for them to use it, like in mono-ethnic families, among friends, reading books, etc. However, maintaining the heritage language is not considered a priority as soon as difficulties arise and when effort is needed to overcome them.

Emigrants from the earlier emigration waves, especially the second wave who left Lithuania due to political reasons, consciously did not only create the Lithuanian environment at home but also founded communities and were devoted to the commitment of maintaining the Lithuanian language and identity. They went to great lengths in order to provide a varied language input in different domains for their children and persevered it in their priorities. The post-Soviet emigrants, on the other hand, do not seem to fully understand the importance of their own behaviour and efforts (or absence thereof) regarding the maintenance of the heritage language in the next generations. They do not sufficiently take advantage of community life as a context for developing better language skills and competences for language use outside the private sphere. They value pragmatic aspects such as communicating with the grandparents or simply an additional language, but do not value language as a core component of ethnic identity.

A point of discussion and direction of further research could be the comparison of the most recent emigration wave with the emigration from Lithuania in 1918-1939. During that period, many Lithuanians went to different countries, quite a few to South America, for economic reasons. They made an effort to quickly integrate into the society of their host countries. Even though they spoke Lithuanian at home and in Lithuanian communities, they wanted their younger generation to quickly learn the local languages (Aleksandravičius 2013, Ramoniene 2019c) and put less effort into the maintenance of the Lithuanian language. Reasons narrated by their descendants are similar to those indicated by the post-Soviet G1s. Currently in most of the Lithuanian communities of that pre-WWII wave of emigration, in Lithuanian families (in Argentina for example), the Lithuanian identity is still maintained, but the intergenerational passing on of the Lithuanian language to the younger generations is discontinued, i.e. the third generation does not know Lithuanian anymore. Naturally, the $21^{\text {st }}$ century provides different possibilities, compared to those a hundred years ago, to maintain connections with the native 
country, with Lithuanian-speaking relatives and friends who live in various places of the world. However, the parallel with a rather similar kind of emigration and its linguistic behaviour makes us think that a similar outcome may await the emigrants of the most recent emigration wave.

(C) Meilutė Ramonienè and Jogilè Teresa Ramonaitė, 2021

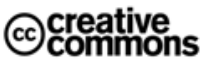

This work is licensed under a Creative Commons Attribution 4.0 International License https://creativecommons.org/licenses/by/4.0/

\section{REFERENCES}

Aleksandravičius, Egidijus. 2013. Karklo Diegas. Lietuviu Pasaulio Istorija [Willow Sprout: A History of the Lithuanian World]. Vilnius: Versus aureus.

Barcevičius, Egidijus. 2012. Emigration and return migration in Central and Eastern Europe: A success story or failed dream? In Egidijus Barcevičius \& Dovilè Žvalionytė (eds.), Užburtas Ratas? Lietuvos Gyventoju Grįžtamoji ir Pakartotine Migracija [Vicious cycle? Analysing return and repeated migration of Lithuanians], 31-74. Vilnius: Vaga. (In Lithuanian)

Bradley, David. 2002. Language attitudes: The key factor in language maintenance. In David Bradley \& Maya Bradley (eds.), Language Endangerment and Language Maintenance: An Active Approach, 1-10. New York: Routledge.

Cidzikaite, Dalia, Dalia Stakè-Anysas \& Laima Petrauskas-VanderStoep. 2014. ,, We Thought We'd Be Back Soon “. 18 Stories of Refugees 1940-1944. Vilnius: Aukso žuvys.

Čiubrinskas, Vytis. 2004. Identity and heritage of Lithuanian-Americans from an anthropological perspective. In Máinréad Craith \& Ullrich Kockel (eds.), Communicating Cultures, 68-82. Berlin: LITVerlag.

Čiubrinskas, Vytis. 2005. Lithuanian Transnationalism: Constructed, imagined and contested identity of Lithuanian Americans. In Egidijus Aleksandravičius, Dalia Kuizinienė \& Milda Danyte (eds.), Beginnings and Ends of Emigration. Life Without Borders in Contemporary World, 33-50. Vilnius: Versus Aureus.

Čiubrinskas, Vytis (ed.). 2011. Lietuviškasis Identitetas Šiuolaikinès Emigracijos Kontekste [Lithuanian identity in the context of modern emigration]. Kaunas: VDU leidykla.

Esman, Milton. J. 1996. Diasporas and international relations. In John Hutchins \& Antony Smith (eds.), Ethnicity, 316-320. New York: Oxford University Press.

Fishman, Joshua. 1991. Reversing Language Shift: Theoretical and Empirical Foundations of Assistance to Threatened Languages. Clevedon: Multilingual Matters.

Garret, Peter, Coupland, Nikolas \& Williams, Angie. 2003. Investigating Language Attitudes. Cardiff: University of Wales Press.

Garret, Peter. 2010. Attitudes to Language. Cambridge: Cambridge University Press.

Gudavičienè, Eglè. 2019. Oslo lietuvių kalbų mokejjimas ir kalbinis elgesys [Lithuanian language proficiency and linguistic behaviour of Oslo Lithuanians]. In Meilutė Ramonienè (ed.), Emigrantai: Kalba ir Tapatybe II [Emigrants: Language and identity II], 149-182. Vilnius: VU leidykla.

Friedman, Jonathan. 2003. Globalizing languages. American Anthropologist 105. 744-752.

Haque, Shahzaman. 2019. Politique Linguistique Familiale /Family Language Policy. Enjeux Dynamiques de la Transmission Linguistique dans un Contexte Migratoire. Dynamics in Language Transmission under a Migratory Context. Munich: LINCOM. 
Hilbig, Inga. 2020. Unharmonious Early Bilingualism in Inter-ethnic Lithuanian Emigrant Families. Taikomoji Kalbotyra 14. 1-20. https://doi.org/10.15388/Taikalbot.2020.14.1 (In Lithuanian)

Jakaitė-Bulbukienè, Kristina. 2015. Lietuviu Emigrantu Šeima: Kalba ir Tapatybè [Lithuanian Emigrant Family: Language and Identity]. Doctoral Dissertation. Vilnius: VU leidykla.

Krupickaite, Dovilè. 2015. Lietuvių diasporos struktūra ir jos atspindys projekto tyrime [The Composition of the Lithuanian Diaspora and its Reflections in the Study]. In Meilute Ramonienè (ed.), Emigrantai: Kalba ir Tapatybe II [Emigrants: Language and identity II], 19-29. Vilnius: VU leidykla.

Kuzmickaite, Daiva Kristina. 2003. Between Two Worlds: Recent Lithuanian Immigrants in Chicago (1988-2000). Vilnius: Versus Aureus.

Kuznecovienè, Jolanta. 2008. Lietuvių tautinis identitetas: Bruožai ir tipai [Lithuanian national identity: features and types]. In Vytis Čiubrinskas \& Jolanta Kuznecovienè (eds.), Lietuviškojo Identiteto Trajektorijos [Trajectories of Lithuanian identity], 55-74. Kaunas: VDU.

Liubinienè, Neringa. 2009. Migrantai iš Lietuvos Šiaurès Airijoje: „Savos erdvès“ konstravimas [Migrants from Lithuania in Northern Ireland: Construction of "own space"]. Doctoral Dissertation. Kaunas: VDU.

Martinaitis, Žilvinas \& Žvalionytè, Dovilè. 2007. Emigracija iš Lietuvos: Ką žinome, ko nežinome ir ką turètume žinoti? [Emigration from Lithuania: What we do, what we should and what we don't know] Politologija 3 (47). 112-134.

Pauwels, Anne. 2016. Language Maintenance and Shift. Cambridge: Cambridge University Press.

Ramonienè, Meilutè. 2015. Kiekybinis ir kokybinis emigrantų kalbos tyrimai [Quantitative and Qualitative Research of emigrant language]. In Meilutė Ramonienė (ed.), Emigrantai: Kalba ir Tapatybe [Emigrants: Language and identity], 31-40. Vilnius: VU leidykla.

Ramoniené, Meilutè. 2019a. Family and the maintenance of the heritage language: The case of Lithuanian diaspora. In Shahzaman Haque (ed.), Politique Linguistique Familiale /Family Language Policy. Enjeux Dynamiques de la Transmission Linguistique dans un Contexte Migratoire. Dynamics in Language Transmission under a Migratory Context, 135-158. Munich: LINCOM.

Ramonienè, Meilutè. 2019b. Migracija, kalba, tapatybè [Migration, language, and identity]. In Meilute Ramonienè (ed.), Emigrantai: Kalba ir Tapatybé II [Emigrants: Language and identity II], 11-21. Vilnius: VU leidykla.

Ramonienè, Meilutè. 2019c. Lietuvybè ir lietuvių kalba Argentinoje [Lithuanian identity and the Lithuanian language in Argentina]. In Meilute Ramonienè (ed.), Emigrantai: Kalba ir Tapatybe II [Emigrants: Language and identity II], 87-108. Vilnius: VU leidykla.

Ramonienè, Meilutè. 2019d. Ką atskleidžia keturi lietuvių diasporos atvejai? [What do four cases of Lithuanian diaspora reveal?] In Meilutè Ramonienè (ed.), Emigrantai: Kalba ir Tapatybe II [Emigrants: Language and identity II], 245-249. Vilnius: VU leidykla.

Sears, David. 1983. The persistence of early political predispositions: The role of attitude object and life stage. In Ladd Wheeler and Philipp Shaver (eds.), Review of Personality and Social Psychology Volume 4, 79-116. Beverly Hills/London/New Delhi: Sage.

Spolsky, Bernard. 2012. Family language policy - The critical domain. Journal of Multilingualism and Multicultural Development 33 (1). 3-11.

Vilkienè, Loreta. 2015. Kalba ir etninè tapatybė [Language and ethnic identity]. In Meilutè Ramonienè (ed.), Emigrantai: Kalba ir Tapatybe [Emigrants: Language and identity], 117-134. Vilnius: VU leidykla.

Vilkienè, Loreta. 2019. Toronto lietuvių bendruomenès lietuviškojo portreto eskizas [A Sketch of the sociolinguistic portrait of the Lithuanian community in Toronto]. In Meilute 
Ramonienė (ed.), Emigrantai: Kalba ir Tapatybe II [Emigrants: Language and identity II], 25-82. Vilnius: VU leidykla.

Wurm, Stephen. 2002. Strategies for language maintenance and revival. In David Bradley \& Maya Bradley (eds.), Language Endangerment and Language Maintenance: An Active Approach, 11-23. New York: Routledge.

\section{Article history:}

Received: 20 May 2021

Accepted: 19 October 2021

\section{Bionotes:}

Meilutė RAMONIENE is a Professor and Director of the Institute of Applied Linguistics at Vilnius University. Her research interests include applied linguistics, sociolinguistics, and teaching Lithuanian as a second language. She is the editor-in-chief of the research journal "Taikomoji kalbotyra".

\section{Contact information:}

Universiteto St 5, LT-01513 Vilnius, Lithuania

e-mail: meilute.ramoniene@flf.vu.lt

ORCID: 0000-0003-4182-4332

Jogilè Teresa RAMONAITE is a fellow researcher at the Institute of the Lithuanian language. Her research interests include psycholinguistics, second language acquisition, and sociolinguistics.

\section{Contact information:}

The Institute of the Lithuanian Language, Department of Sociolinguistics, P. Vileišio st. 5, LT-10308, Vilnius, Lithuania

e-mail: jogileteresa@sociolingvistika.lt

ORCID: 0000-0002-2988-5194

\section{Сведения об авторах:}

Мейлуте РАМОНЕНЕ - профессор и директор Института прикладной лингвистики Вильнюсского университета. Сферы научных интересов: прикладная лингвистика, социолингвистика, обучение литовскому языку как неродному. М. Рамонене является главный редактором научного журнала "Тaikomoji kalbotyra".

\section{Контактная информация:}

Universiteto St 5, LT-01513 Vilnius, Lithuania

e-mail: meilute.ramoniene@flf.vu.lt

ORCID: 0000-0003-4182-4332

Йогиле Тереса РАМОНАЙТЕ - научный сотрудник Института литовского языка. Сферы еe научных интересов: психолингвистика, усвоение второго языка, социолингвистика.

\section{Контактная информация:}

The Institute of the Lithuanian Language, Department of Sociolinguistics, P. Vileišio st. 5, LT-10308, Vilnius, Lithuania e-mail: jogileteresa@sociolingvistika.lt

ORCID: 0000-0002-2988-5194 